\title{
Recovery of Gallium from Bauxite Residue Using Combined Oxalic Acid Leaching with Adsorption onto Zeolite HY
}

\author{
Éva Ujaczki ${ }^{1,2,3} \cdot$ Ronan Courtney $^{2,4} \cdot$ Patricia Cusack $^{2,4} \cdot$ Rama Krishna Chinnam $^{1,2,5} \cdot$ Seamus Clifford ${ }^{2,6}$. \\ Teresa Curtin ${ }^{2,7} \cdot$ Lisa O'Donoghue $^{1,2}$
}

Published online: 4 June 2019

(c) The Author(s) 2019

\begin{abstract}
Bauxite residue, the byproduct of alumina production, may potentially be a valuable source of strategically important metals, e.g. Gallium. Ga is considered critical element for the EU. To ensure adequate supply of Ga for the future, secondary sources such as bauxite residue should be exploited with efficient extraction methods. Therefore, in this study, mineral acids $\left(\mathrm{H}_{2} \mathrm{SO}_{4}\right.$, $\mathrm{HCl}$, and $\left.\mathrm{HNO}_{3}\right)$ and an organic acid $\left(\mathrm{H}_{2} \mathrm{C}_{2} \mathrm{O}_{4}\right.$ - oxalic acid), were evaluated for their efficiencies to extract $\mathrm{Ga}$ from bauxite residue. Using $\mathrm{H}_{2} \mathrm{C}_{2} \mathrm{O}_{4}$, the highest $\mathrm{Ga}$ leaching efficiencies were achieved, compared to other acids. The achieved leaching experimental results were considered for the construction of a design of experiment (DOE) model to achieve optimal conditions for $\mathrm{Ga}$ extraction using $\mathrm{H}_{2} \mathrm{C}_{2} \mathrm{O}_{4}$. These values were validated by experiments which resulted in $\sim 94 \%$ accuracy. In the second part of the study, using pure Ga solution, the adsorption of Ga onto zeolite HY was studied. The effects of adsorbent dosage, temperature, and contact time on the adsorption of Ga from solution by zeolite HY were studied. The obtained adsorption experimental results were used to construct a DOE model to achieve optimal conditions for Ga adsorption on to zeolite HY. The DOE-achieved optimal conditions were evaluated by experiments in pure Ga solution, which resulted in an efficiency of $\sim 99.4 \%$. In the third stage, the bauxite residue was leached in $\mathrm{H}_{2} \mathrm{C}_{2} \mathrm{O}_{4}$ under the optimal DOE conditions which resulted in $71 \%$ efficiency; thus the resulting bauxite residue solution was subjected to adsorption using zeolite HY under the optimal DOE conditions achieved. The Ga adsorption onto the zeolite was only $16 \%$ compared to the Ga adsorption of 99.4 $\%$ under the pure Ga solution, thus, representing the influences of the other leachates in the solution, which are minimizing the $\mathrm{Ga}$ adsorption onto the zeolite $\mathrm{HY}$ and providing an opportunity for future studies on the different mechanisms involved.
\end{abstract}

Keywords Bauxite residue $\cdot$ Critical raw materials $\cdot$ Extraction $\cdot$ Adsorption $\cdot$ Design of experiments $\cdot$ Oxalic acid $\cdot$ Zeolite

The contributing editor for this article was D. Panias.

Electronic supplementary material The online version of this article (doi:https://doi.org/10.1007/s40831-019-00226-w) contains supplementary material, which is available to authorized users.

Éva Ujaczki

Eva.Ujaczki@ul.ie

1 School of Engineering, University of Limerick, Limerick, Ireland

2 The Bernal Institute, University of Limerick, Limerick, Ireland

3 Department of Applied Biotechnology and Food Science, Faculty of Chemical Technology and Biotechnology, Budapest University of Technology and Economics, Múegyetemrkp. 3, Budapest 1111, Hungary

\section{Introduction}

Recent studies by major economies [1-4] have identified strategically important elements, called critical raw materials (CRMs), for their economy. These are defined as materials with a high supply risk and an above average

4 Biological Sciences Department, University of Limerick, Limerick, Ireland

5 Department of Materials Science and Engineering, University of Erlangen-Nuremberg, Cauerstr. 6, 91058 Erlangen, Germany

6 Enterprise Research Centre, University of Limerick, Limerick, Ireland

7 Chemical Sciences Department, University of Limerick, Limerick, Ireland 
economic importance compared to other raw materials [5]. The European Commission (EC) is implementing a wide range of actions under the EU Raw Materials Initiative to help ensure their secure, sustainable and affordable supply [1]. One approach to reduce the supply risk of CRM is to utilize previously untapped primary and secondary sources [6].

Bauxite residue, a potential secondary source of CRM, can contain considerable amounts of strategically important metals depending on its geologic origin and processing $[6,7]$. Bauxite residue is the byproduct of alumina production and is generated in the Bayer process when bauxite is digested in hot $\mathrm{NaOH}$ under elevated temperature and pressure. It is available at a multimillion ton scale worldwide as the global inventory of bauxite residue already reached an estimated 2.7 billion tons by 2011 [8] with an annual production rate of 150 million tons [9]. Numerous studies have focused on the utilization of bauxite residue as a source for the production of major elements (e.g., blast furnace for pig iron production [10-14]) or as a source of rare earth elements (REEs) [15-19] as well as the combination of these [20]. Fewer efforts have been made to use the bauxite residue as a secondary source of other CRMs such as $\mathrm{V}$ and $\mathrm{Ga}$ $[18,21,22]$.

According to EC reports, $\mathrm{Ga}$ is considered as a strategically important metal for the EU since 2011 [1, 23, 24]. The Ga presence in the Earth`s crust is small $(<19 \mathrm{mg} /$ $\mathrm{kg}$ ) therefore there is no primary Ga mine. Ga appears in trace amounts $(<50 \mathrm{ppm})$ as a salt in bauxite and zinc ores [25] and it is therefore extracted from bauxite as part of the bauxite-alumina-aluminum refining flow. Although some $\mathrm{Ga}$ is also derived from the processing of sphalerite ore for zinc, it is also recycled from the slag generated during the manufacture of gallium arsenide (GaAs)- and gallium nitride ( $\mathrm{GaN}$ )-based devices [26]. Compounds of Ga such as $\mathrm{GaAs}, \mathrm{GaN}$, and copper-indium-gallium selenide (CIGS) possess semiconducting properties, and therefore, they are used for the production of microelectronic components [26]. World demand for GaAs- and GaN-based products increased during the past few decades, and it is expected to remain still high [27]. To ensure adequate supplies of Ga for the future, secondary sources such as bauxite residue should be exploited with efficient extraction methods.

The most widely used strategy for extraction of economically interesting elements from bauxite residue is direct hydrometallurgical leaching [16,18,28-30]. Technologies have been investigated for major metal ( $\mathrm{Al}, \mathrm{Fe}$, and $\mathrm{Ti}$ ) recovery by pyrometallurgical/mechanical operations (reductive smelting, roasting) and combinations of the latter with hydrometallurgical leaching [11, 12, 20, 31, 32]. Extraction of valuable elements requires the use of additional chemicals and energy: e.g., in direct hydrometallurgical leaching, mineral acids such as $\mathrm{H}_{2} \mathrm{SO}_{4}, \mathrm{HCl}$, and $\mathrm{HNO}_{3}$ are primarily used at high temperatures [6, 33-36].

Previous studies on extraction of Ga from bauxite residue have been based on mineral acids $[18,22]$ and on alkaline solutions from bauxite residue (hydrogarnet process) [21]. In the latter, the extraction of Ga from bauxite residue was carried out in high modulus alkaline solution $(240 \mathrm{~g} / \mathrm{L}$ $\left.\mathrm{Na}_{2} \mathrm{O} ; \alpha_{\mathrm{K}}=30\right)$ at high temperatures $\left(240-260{ }^{\circ} \mathrm{C}\right)$ in the presence of lime followed by treatment of the leachate by $\mathrm{CO}_{2}$-enriched air [21].

Lu et al. [22] presented a method called acidic-leachingion-exchange process (ALIEP) to extract Ga from bauxite residue. The ALIEP method mainly consisted of three steps: extraction of $\mathrm{Ga}$ from bauxite residue by mineral acid $(\mathrm{HCl})$, removal of $\mathrm{Fe}^{3+}$ from the leaching solution by chlorinated polystyrene macroporous (LSD-369) resin (adsorbent), and recovery of $\mathrm{Ga}$ from the leaching solution by LSC$500 \mathrm{~S}$ resin. LSC-500S resin contained reactive groups of $\left[-\mathrm{NH}-\mathrm{CH}_{2}-\mathrm{P}(\mathrm{O})(\mathrm{OH})_{2}\right]$ and was able to form stable complexes through reactive groups binding with metal ions. In Lu et al.'s [22] study, $94.8 \% \mathrm{Ga}$ was extracted from bauxite residue at $4.4 \mathrm{M} \mathrm{HCl}, 4 \mathrm{~h}, 55^{\circ} \mathrm{C}, 125 \mathrm{~g} / \mathrm{L}$ slurry concentration; and $59.8 \% \mathrm{Ga}$ was adsorbed from $\mathrm{HCl}$ leachate on the LSC-500S resin under conditions of $8 \mathrm{~g} / \mathrm{L}$ resin dosage, $24 \mathrm{~h}$, and $45^{\circ} \mathrm{C}$.

The extraction of CRMs such as Ga and REEs from bauxite residue by selective acid leaching was explored by Ujaczki et al. [18, 19]. After acidic extraction, CRMs were purified by liquid-liquid extraction using di-(2-ethylhexyl) phosphoric acid (D2EHPA) dissolved in kerosene. According to Ujaczki et al. [18, 19], 87.6\% Ga was extracted from bauxite residue under conditions: $6.0 \mathrm{M} \mathrm{HCl}, 21 \mathrm{~h}, 50{ }^{\circ} \mathrm{C}$, $56.7 \mathrm{~g} / \mathrm{L}$ slurry concentration; and $29.0 \% \mathrm{Ga}$ was extracted from $\mathrm{HCl}$ leachate to the organic solvent phase (D2EHPA in kerosene) under conditions: 0.1 organic/aqueous ratio, 0.78 M D2EHPA concentration in kerosene, $1 \mathrm{~h}$, and $22^{\circ} \mathrm{C}$.

Both studies showed a potential in extraction of $\mathrm{Ga}$ from bauxite residue by acidic leaching. Moreover, adsorption onto LSC-500S resin by Lu et al. [22] showed higher efficiency than separation by liquid-liquid extraction using D2EHPA dissolved in kerosene [19]. In addition, Ujaczki et al. [18] evaluated efficiencies of conventional extracting agents (mineral acids) and small molecular weight complexing agents (organic acids) to extract CRM such as $\mathrm{Ga}$ from bauxite residue. They found that the use of oxalic acid $\left(\mathrm{H}_{2} \mathrm{C}_{2} \mathrm{O}_{4}\right)$ resulted in the most efficient extraction of $\mathrm{Ga}$ with, at the same time, lower extractions of $\mathrm{Fe}$ and $\mathrm{Al}$.

In the present study, mineral acids $\left(\mathrm{H}_{2} \mathrm{SO}_{4}, \mathrm{HCl}\right.$, and $\left.\mathrm{HNO}_{3}\right)$ and organic acid $\left(\mathrm{H}_{2} \mathrm{C}_{2} \mathrm{O}_{4}\right)$ were evaluated regarding their efficiencies to extract $\mathrm{Ga}$ from bauxite residue. As a consequence of previous studies $[18,22]$ and the present comparison, $\mathrm{H}_{2} \mathrm{C}_{2} \mathrm{O}_{4}$ was found to be the most efficient acid for the extraction of $\mathrm{Ga}$ from bauxite residue, and therefore, 
parameters for the extraction by $\mathrm{H}_{2} \mathrm{C}_{2} \mathrm{O}_{4}$ were also investigated. For the first time, experiments for adsorption onto zeolite for recovering $\mathrm{Ga}$ from $\mathrm{H}_{2} \mathrm{C}_{2} \mathrm{O}_{4}$ leachate were conducted. The effects of adsorbent dosage, temperature, and contact time on the removal of Ga by zeolite HY from synthetic Ga solution were also studied. The optimization was achieved with the help of experimental design (DOE) software analysis which was validated with experiments. The residue left after the processing (post residue) was characterized to understand the influences of extraction process on the $\mathrm{pH}$ change, morphology, and chemical change.

\section{Materials and Methods}

\section{Physicochemical and Mineralogical Characterization}

The bauxite residue $(\mathrm{pH} 10.9, \mathrm{EC}=0.9 \mathrm{mS}$ and $28 \%$ moisture content) used in this study was produced by the Bayer process, stored after dewatering by vacuum filtration and mud farming at the disposal area. Samples were dried at $105^{\circ} \mathrm{C}$ for $24 \mathrm{~h}$, pulverized using a mortar and pestle and sieved to a particle size of $<2 \mathrm{~mm}$. The $\mathrm{pH}$ and electrical conductivity (EC) were measured using $5 \mathrm{~g}$ sample in aqueous extract at 1:5 ratio (solid:liquid) with an Aqualytic AL15 multimeter [37]. X-ray fluorescence (XRF) analysis was carried out using a Panalytical Axios XRF. Scanning electron microscopy (SEM) and energy-dispersive X-ray spectroscopy (EDS) was performed on Hitachi SU-70 microscope.

\section{Elemental Analyses}

Elemental analysis was performed after aqua regia digestion at 1:10 ratio (solid:liquid) in Multiwave 3000 (Rotor 8XF100) microwave digestion system at $200{ }^{\circ} \mathrm{C}$ and 1.25 MPa. The solutions after digestion were filtered with a $0.45 \mu \mathrm{m}$ PVDF syringe filter and diluted in $1 \mathrm{M} \mathrm{HNO}_{3}$ before analysis [18]. An Agilent Technologies 5100 inductively coupled plasma optical emission spectrometer (ICPOES) was used for metal analysis. Standard solutions and samples were diluted with $1 \mathrm{M} \mathrm{HNO}_{3}$. The following analytical line (in $\mathrm{nm}$ ) was used for calculations: $\mathrm{Al} 308.215$, 394.401, 396.152; Ca 396.847, 422.673; Fe 234.350; Ga 294.363; Na 589.592; Si 250.690, 251.611, 288.158; Ti $334.188,336.122$, 368.520; V 268.796 [38].

\section{Leaching Study}

The comparative metal leaching tests were performed with equivalent normality acids $\left(1 \mathrm{M} \mathrm{H}_{2} \mathrm{SO}_{4}, 2 \mathrm{M} \mathrm{HNO}_{3}, 2 \mathrm{M}\right.$ $\left.\mathrm{HCl}, 1 \mathrm{M} \mathrm{H}_{2} \mathrm{C}_{2} \mathrm{O}_{4}\right)$ at $60{ }^{\circ} \mathrm{C}, 24 \mathrm{~h}, 100 \mathrm{~g} / \mathrm{L}$ slurry concentration in triplicate [18]. All tests were carried out in $100 \mathrm{ml}$ conical flasks. These were shaken on an IKA KS
$4000 \mathrm{i}$ control incubation shaker at $250 \mathrm{rpm}$. Further leaching tests were carried out with $\mathrm{H}_{2} \mathrm{C}_{2} \mathrm{O}_{4}$ by varying several parameters, i.e. acid concentration $(0.05-3 \mathrm{M})$, contact time (1-24 h) temperature $\left(20-80^{\circ} \mathrm{C}\right)$ and slurry concentration (10-200 g/L). The acid concentration, contact time and temperature were extended for every extraction step to ensure that the leaching equilibrium (i.e. plateau of the kinetic) was reached.

The bauxite residue leachate solutions were centrifuged for $5 \mathrm{~min}$ at $3500 \mathrm{rpm}$ and $20^{\circ} \mathrm{C}$ (Sorvall TC-6), filtered, diluted in $1 \mathrm{M} \mathrm{HNO}_{3}$ and analyzed by ICP-OES as described above. The extraction efficiencies were determined by the ratio of metal extracted to the aqua regia-accessible metal content ("Elemental Analyses" section).

\section{Adsorption Study}

Comparative experiments on $\mathrm{Ga}$ adsorption were conducted with three types of zeolites (HY, H-beta, ZSM-5) (see Supporting Information [SI], Table 1). Stock solution of $50 \mathrm{mg} / \mathrm{L} \mathrm{Ga}$ was prepared by diluting $1000 \mathrm{mg} / \mathrm{L} \mathrm{Ga}$ standard solution (certified reference material, matrix: $7 \% \mathrm{HNO}_{3}$ ). All tests were carried out in $100 \mathrm{~mL}$ conical flasks with constant shaking at $250 \mathrm{rpm}$. Further adsorption tests were carried out with zeolite HY by varying several parameters, i.e. adsorbent dosage $(0.4-25.0 \mathrm{mg} / \mathrm{mL})$, contact time $(0-24 \mathrm{~h})$ and temperature $\left(20-80{ }^{\circ} \mathrm{C}\right)$. Following selection of optimum adsorption parameters the zeolite $\mathrm{HY}$ was investigated for adsorption of $\mathrm{Ga}$ from bauxite residue $\mathrm{H}_{2} \mathrm{C}_{2} \mathrm{O}_{4}$ leachate. The adsorbent was separated from the solution by a $0.45 \mu \mathrm{m}$ PVDF syringe filter and diluted in $1 \mathrm{M} \mathrm{HNO}_{3}$ before analysis by ICP-OES as described above ("Elemental Analyses" section). The adsorption efficiencies were determined by the ratio of metal analyzed to the stock solution and to the $\mathrm{H}_{2} \mathrm{C}_{2} \mathrm{O}_{4}$ leachate metal content, respectively. The adsorption isotherm was calculated using the following equation:

$q_{\mathrm{e}}=\frac{\left(C_{0}-C_{\mathrm{e}}\right) \cdot V}{X}$,

where $q_{\mathrm{e}}$ is the amount of adsorbate in the adsorbent at equilibrium $(\mathrm{mg} / \mathrm{g}), C_{0}$ is the initial adsorbate concentration $(\mathrm{mg} / \mathrm{L}), C_{\mathrm{e}}$ is the adsorbate equilibrium concentration $(\mathrm{mg} / \mathrm{L}), V$ is the volume of the solution $(\mathrm{L})$, and $X$ is the mass of adsorbent (g).

\section{Post Residue Characterization}

The residue left after the processing (post residue) was characterized by $\mathrm{pH}$ and EC multimeter, XRD, and SEM-EDS as described in "Physicochemical and Mineralogical Characterization" section. Prior to the analysis, samples were dried at $105^{\circ} \mathrm{C}$ for $24 \mathrm{~h}$, pulverized using a mortar and pestle, and sieved to a particle size of $<2 \mathrm{~mm}$. 


\section{Experimental Design and Statistical Analysis}

Minitab 17 software was used for the development and analysis of experimental designs using the response surface methodology. In the leaching study, a linear model was fitted to the maximal extracted $\mathrm{Ga}$ which was recovered by extraction with $\mathrm{H}_{2} \mathrm{C}_{2} \mathrm{O}_{4}$ under varied parameters. The effects of four factors were considered i.e. $\mathrm{H}_{2} \mathrm{C}_{2} \mathrm{O}_{4}$ concentration, contact time, temperature and slurry concentration. In the adsorption study, a linear model was fitted to the removal of maximal $\mathrm{Ga}$ from solution under varied parameters. The effects of three factors were considered i.e. adsorbent dosage, contact time and temperature. Both models were subsequently reduced to only contain potentially significant factors $(p \leq 0.05)$ and factors necessary to maintain model hierarchy using the stepwise automatic model regression of the software. The proposed optimal parameters were tested afterwards experimentally.

\section{Results}

\section{Bauxite Residue Composition}

The elemental composition of the bauxite residue was dominated by $\mathrm{Fe}(\sim 43.3 \%)$, $\mathrm{Al}(\sim 16.5 \%)$, Si $(\sim 9.4 \%)$, Ti ( $8.9 \%), \mathrm{Ca}(\sim 6.2 \%)$ and $\mathrm{Na}(\sim 6.0 \%)$ oxides as detected by XRF (SI, Table 2); the Ga concentration was $114.5 \pm 5.2 \mathrm{mg} /$ $\mathrm{kg}$ which was analyzed by ICP-OES (SI, Table 3). Additional characterization of physicochemical, elemental and mineralogical composition of bauxite residue in storage over a 12-year period was carried out by Cusack et al. [39] They found that the main mineralogical composition of the bauxite residue detected by XRD included haematite $\left(\mathrm{Fe}_{2} \mathrm{O}_{3}\right)$, goethite $[\mathrm{FeO}(\mathrm{OH})]$, perovskite $\left(\mathrm{CaTiO}_{3}\right)$, rutile $\left(\mathrm{TiO}_{2}\right)$, gibbsite $\left[\mathrm{Al}(\mathrm{OH})_{3}\right]$, sodalite $\left[\mathrm{Na}_{8}\left(\mathrm{Al}_{6} \mathrm{Si}_{6} \mathrm{O}_{24}\right) \mathrm{Cl}_{2}\right]$, and cancrinite $\left[\mathrm{Na}_{6} \mathrm{Ca}_{2}\left(\mathrm{CO}_{3}\right)\right]$ (Cusack et al. [39]).

\section{Comparative Metal Acid Leaching Study}

Three mineral acids $\left(\mathrm{HCl}, \mathrm{HNO}_{3}, \mathrm{H}_{2} \mathrm{SO}_{4}\right)$ and an organic acid $\left(\mathrm{H}_{2} \mathrm{C}_{2} \mathrm{O}_{4}\right)$ were used for the extraction of Ga from bauxite residue at normality $=2,24 \mathrm{~h}, 60^{\circ} \mathrm{C}, 100 \mathrm{~g} / \mathrm{L}$ slurry concentration and $250 \mathrm{rpm}$. This comparative extraction study showed that the most efficient extraction for Ga was achieved by $\mathrm{H}_{2} \mathrm{C}_{2} \mathrm{O}_{4}(39 \%-44.8 \mathrm{mg} / \mathrm{kg})$ followed by acids in the order $\mathrm{HCl}(32 \%-37.2 \mathrm{mg} / \mathrm{kg})>\mathrm{H}_{2} \mathrm{SO}_{4}(27 \%-30.6 \mathrm{mg} / \mathrm{kg})>\mathrm{HNO}_{3}$ (26\%-29.8 mg/kg) (SI, Table 4). Therefore, $\mathrm{H}_{2} \mathrm{C}_{2} \mathrm{O}_{4}$ was chosen for further investigation of leaching parameters. $\mathrm{Al}$ and $\mathrm{Fe}$ leaching were also investigated as they were major elements in the bauxite residue and their leaching selectivity is an important factor. Using $1 \mathrm{M}(2 \mathrm{~N}) \mathrm{H}_{2} \mathrm{C}_{2} \mathrm{O}_{4}, 54 \%$ $(\sim 49,802 \mathrm{mg} / \mathrm{kg}) \mathrm{Al}$ and $23 \%(\sim 81,563 \mathrm{mg} / \mathrm{kg})$ Fe were also coextracted under the above conditions (SI, Table 4).

\section{Effect of Leaching Parameters}

The effect of acid concentration, temperature, contact time and slurry concentration on the extraction of $\mathrm{Al}, \mathrm{Fe}$ and $\mathrm{Ga}$ from bauxite residue were studied (Fig. 1) [40]. Increasing the $\mathrm{H}_{2} \mathrm{C}_{2} \mathrm{O}_{4}$ concentration from 0.05 to $3 \mathrm{M}$ increased extraction efficiencies of $\mathrm{Ga}$ from $3 \%(\sim 3.6 \mathrm{mg} / \mathrm{kg})$ to $44 \%$ $(\sim 50.9 \mathrm{mg} / \mathrm{kg})$ at $24 \mathrm{~h}, 60{ }^{\circ} \mathrm{C}, 100 \mathrm{~g} / \mathrm{L}$ slurry concentration and $250 \mathrm{rpm} .41 \%(\sim 44.1 \mathrm{mg} / \mathrm{kg}) \mathrm{Ga}$ extraction efficiency was already achieved using $1 \mathrm{M} \mathrm{H}_{2} \mathrm{C}_{2} \mathrm{O}_{4}$, therefore, $1 \mathrm{M} \mathrm{H}_{2} \mathrm{C}_{2} \mathrm{O}_{4}$ was chosen for the remaining leaching experiments. Increasing the contact time from 1 to $24 \mathrm{~h}$ increased extraction efficiencies of $\mathrm{Ga}$ from $12 \%(\sim 13.8 \mathrm{mg} / \mathrm{kg})$ to $38 \%(\sim 44.1 \mathrm{mg} / \mathrm{kg})$ using $1 \mathrm{M} \mathrm{H}_{2} \mathrm{C}_{2} \mathrm{O}_{4}, 60{ }^{\circ} \mathrm{C}, 100 \mathrm{~g} / \mathrm{L}$ slurry concentration and $250 \mathrm{rpm}$. Also, elevating the temperature from 22 to $80{ }^{\circ} \mathrm{C}$ led to considerably increased extraction efficiencies of $\mathrm{Ga}$ from $18 \%(\sim 19.5 \mathrm{mg} / \mathrm{kg})$ to $40 \%(\sim 42.7 \mathrm{mg} / \mathrm{kg})$ using $1 \mathrm{M} \mathrm{H}_{2} \mathrm{C}_{2} \mathrm{O}_{4}, 24 \mathrm{~h}, 100 \mathrm{~g} / \mathrm{L}$ slurry concentration and $250 \mathrm{rpm}$. The slurry concentration had a strong effect on extraction efficiencies similar to the acid concentration. Here, decreasing slurry concentration from 200 to $10 \mathrm{~g} / \mathrm{L}$ resulted an increase in extraction efficiencies of $\mathrm{Ga}$ from $3 \%(\sim 3.7 \mathrm{mg} / \mathrm{kg})$ to $47 \%(\sim 53.9 \mathrm{mg} / \mathrm{kg})$ at $1 \mathrm{M}$ $\mathrm{H}_{2} \mathrm{C}_{2} \mathrm{O}_{4}, 24 \mathrm{~h}, 60^{\circ} \mathrm{C}$ and $250 \mathrm{rpm}$.

Similar trends were identified for $\mathrm{Al}$ and $\mathrm{Fe}$ extractions (Fig. 1). Using $1 \mathrm{M} \mathrm{H}_{2} \mathrm{C}_{2} \mathrm{O}_{4}$ resulted in the extraction of $57 \%$ $(\sim 52,316 \mathrm{mg} / \mathrm{kg})$ of $\mathrm{Al}$ and $22 \%(\sim 75,447 \mathrm{mg} / \mathrm{kg})$ of $\mathrm{Fe}$ at $24 \mathrm{~h}, 60{ }^{\circ} \mathrm{C}, 100 \mathrm{~g} / \mathrm{L}$ slurry concentration, and $250 \mathrm{rpm}$. Elevated temperature increased the $\mathrm{Al}$ extraction efficiency to $63 \%(\sim 58,102 \mathrm{mg} / \mathrm{kg})$ of $\mathrm{Al}$, while Fe still remained at $21 \%(\sim 74,345 \mathrm{mg} / \mathrm{kg})$ at $1 \mathrm{M} \mathrm{H}_{2} \mathrm{C}_{2} \mathrm{O}_{4}, 24 \mathrm{~h}, 100 \mathrm{~g} / \mathrm{L}$ slurry concentration, and $250 \mathrm{rpm}$. The maximal $\mathrm{Al}$ and $\mathrm{Fe}$ extraction efficiencies were achieved by decreasing slurry concentration to $10 \mathrm{~g} / \mathrm{L}$ resulting in $62 \%(\sim 54,775 \mathrm{mg} / \mathrm{kg})$ of $\mathrm{Al}$ and $62 \%(\sim 21,6378 \mathrm{mg} / \mathrm{kg})$ of Fe extracted using $1 \mathrm{M} \mathrm{H}_{2} \mathrm{C}_{2} \mathrm{O}_{4}$, $24 \mathrm{~h}, 60^{\circ} \mathrm{C}$, and $250 \mathrm{rpm}$.

\section{Design of Experiment Approach to Predict the Optimal Parameters for Leaching Experiments}

In order to determine optimal extraction conditions to extract maximal $\mathrm{Ga}$ in bauxite residue, a design of experiment (DOE) approach was used to account for interaction effects between investigated factors regarding acid concentration (0.05-3 $\mathrm{M} \mathrm{H}_{2} \mathrm{C}_{2} \mathrm{O}_{4}$ ), contact time (1-24 h), temperature $\left(50-80{ }^{\circ} \mathrm{C}\right)$, and slurry concentration $(10-200 \mathrm{~g} / \mathrm{L})$ (SI, Table 5). The response surface-reduced linear model 

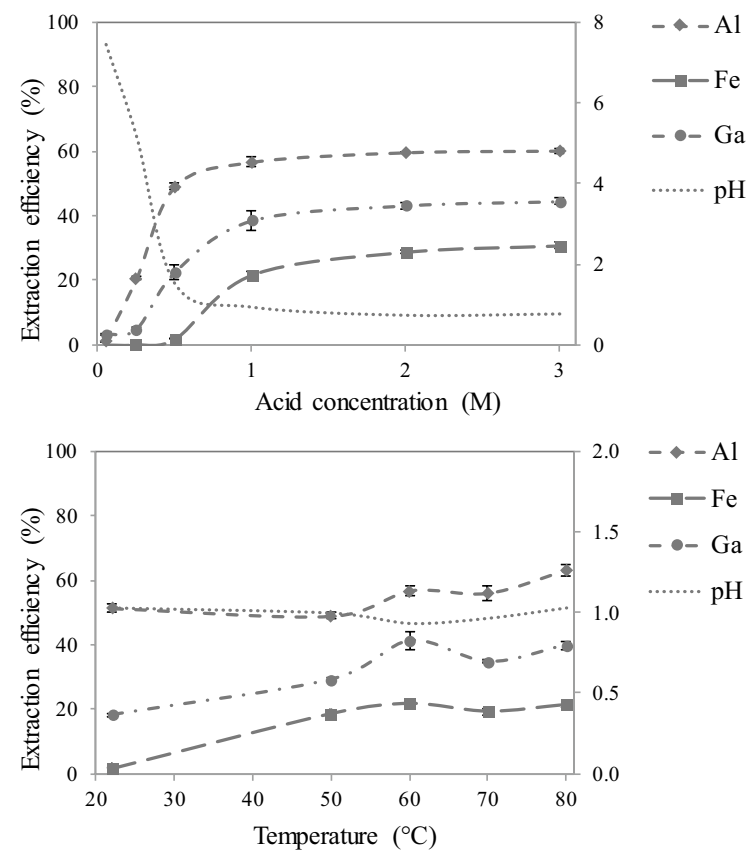

Fig. 1 Effects of leaching parameters $\left(\mathrm{H}_{2} \mathrm{C}_{2} \mathrm{O}_{4}\right.$ concentration, contact time, temperature, slurry concentration) on extraction efficiency (primary $Y$-axis) and $\mathrm{pH}$ (secondary $Y$-axis) of $\mathrm{Al}, \mathrm{Fe}$, and $\mathrm{Ga}$. Single

considered linear effects between the investigated parameters (SI, Eq. 1) when all linear effects of the four tested factors had a significant $(p \leq 0.05)$ effect on the extracted $\mathrm{Ga}$ (SI, Table 6). Figure 2 shows the two-factor-interaction effects between contact time and $\mathrm{H}_{2} \mathrm{C}_{2} \mathrm{O}_{4}$ concentration (Fig. 2a); temperature and $\mathrm{H}_{2} \mathrm{C}_{2} \mathrm{O}_{4}$ concentration (Fig. 2b); and slurry concentration and $\mathrm{H}_{2} \mathrm{C}_{2} \mathrm{O}_{4}$ concentration (Fig. 2c).

$\mathrm{H}_{2} \mathrm{C}_{2} \mathrm{O}_{4}$ concentration, contact time and temperature had the most pronounced effect on the extracted $\mathrm{Ga}$ (ranging from 3.0 to $63.1 \mathrm{mg} / \mathrm{kg}$ while leaving the other factors at optimal values) and are, therefore, the most important factors to optimize. Slurry concentration had a considerably lower impact.

Optimal conditions predicted by the model regarding extraction of maximal $\mathrm{Ga}$ from bauxite residue were $2.5 \mathrm{M}$ $\mathrm{H}_{2} \mathrm{C}_{2} \mathrm{O}_{4}$ acid concentration, 21.7 -h contact time, $80.0{ }^{\circ} \mathrm{C}$ temperature, and $10.0 \mathrm{~g} / \mathrm{L}$ slurry concentration. The model predicted maximal extracted $\mathrm{Ga}$ of $85.8 \mathrm{mg} / \mathrm{kg}$. The corresponding leaching experiment under these conditions was conducted, which yielded a maximal extracted $\mathrm{Ga}$ of $81.1 \mathrm{mg} / \mathrm{kg}$. Since the experimentally determined and predicted maximal extractable Ga did not differ significantly (prediction was 93\% of the obtained), the model was considered accurate. Using these optimal conditions, $71 \%$ of the aqua regia-accessible $\mathrm{Ga}$ content was extracted from bauxite residue.
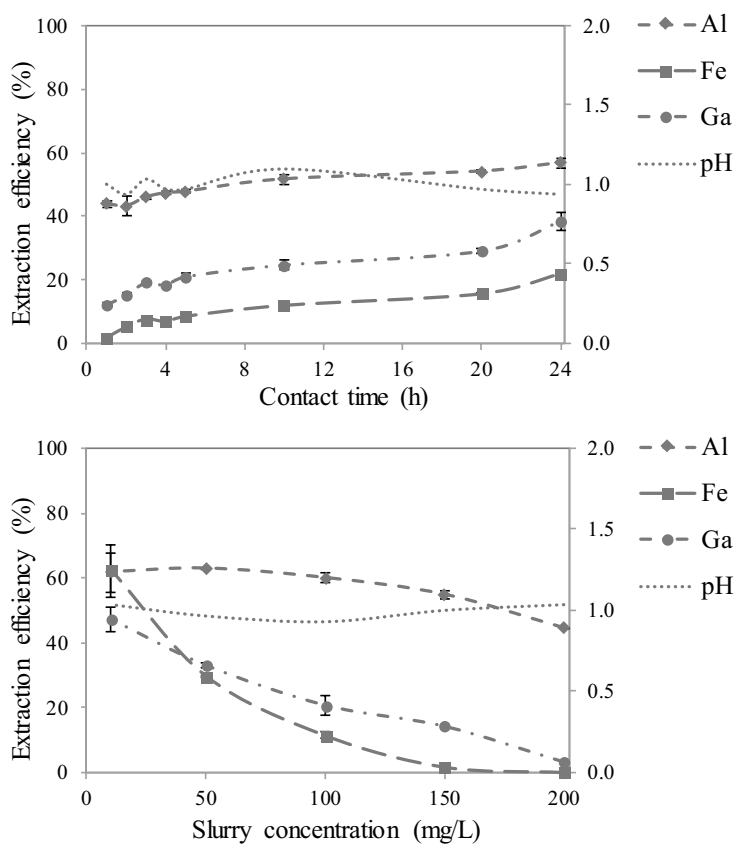

parameters were varied, whereas all other parameters were kept constant at $\left(1 \mathrm{M} \mathrm{H}_{2} \mathrm{C}_{2} \mathrm{O}_{4}, 24 \mathrm{~h}, 60{ }^{\circ} \mathrm{C}\right.$, and $100 \mathrm{~g} / \mathrm{L}$ slurry concentration)

\section{Adsorption Study}

For the first time this study showed a process combination of acid leaching and adsorption on zeolite for the recovery of $\mathrm{Ga}$ from bauxite residue, therefore process parameters were developed for the study in batch experiments using model solutions contain $\mathrm{Ga}$.

In the batch study, the removal of $\mathrm{Ga}$ from $\mathrm{Ga}(50 \mathrm{mg} / \mathrm{L})$ solution by three types of zeolites (HY, H-beta, ZSM-5) were compared (SI, Table 1). Among the investigated zeolite products, the zeolite HY showed the highest Ga sorption capacity from the solution with the $99 \%(\sim 49.6 \mathrm{mg} / \mathrm{L}) \mathrm{Ga}$ removal efficiency under the following conditions $10 \mathrm{mg} /$ $\mathrm{mL}$ amount of adsorbent, 24-h contact time, and $20^{\circ} \mathrm{C}$ (SI, Table 7).

The effect of adsorbent dosage, temperature and contact time on the removal of Ga by zeolite HY from Ga solution were studied (Fig. 3). Increasing the adsorbent dosage from 0 to $25 \mathrm{mg} / \mathrm{mL}$ increased removal efficiencies of $\mathrm{Ga}$ from $0 \%(\sim 0.1 \mathrm{mg} / \mathrm{L})$ to $100 \%(\sim 49.9 \mathrm{mg} / \mathrm{L})$ at $24 \mathrm{~h}$ and $20^{\circ} \mathrm{C}$. The Ga removal efficiency was already $90 \%$ at $5 \mathrm{mg} / \mathrm{mL}$ adsorbent dosage, therefore, it was used for investigating the effect of temperature and contact time. Temperature had no particular effect on the removal of $\mathrm{Ga}$ in the range of $20-80{ }^{\circ} \mathrm{C}$. Increasing contact time increased removal efficiencies of $\mathrm{Ga}$ from $5 \%(\sim 2.6 \mathrm{mg} / \mathrm{L})$ to $90 \%(\sim 44.8 \mathrm{~g} / \mathrm{L})$ using $5 \mathrm{~g} / \mathrm{mL}$ amount of adsorbent at $20^{\circ} \mathrm{C}$. Ga adsorption 

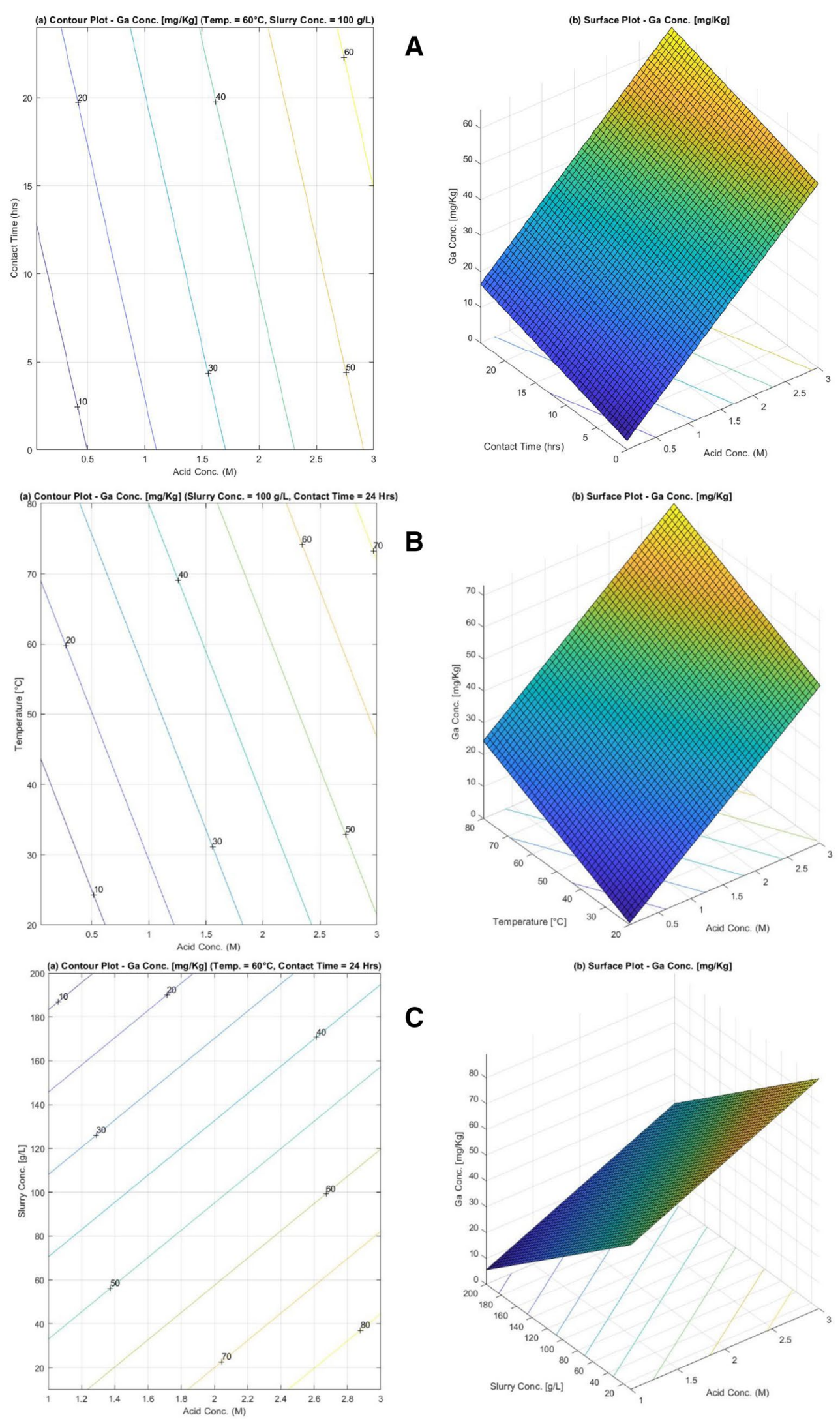

C

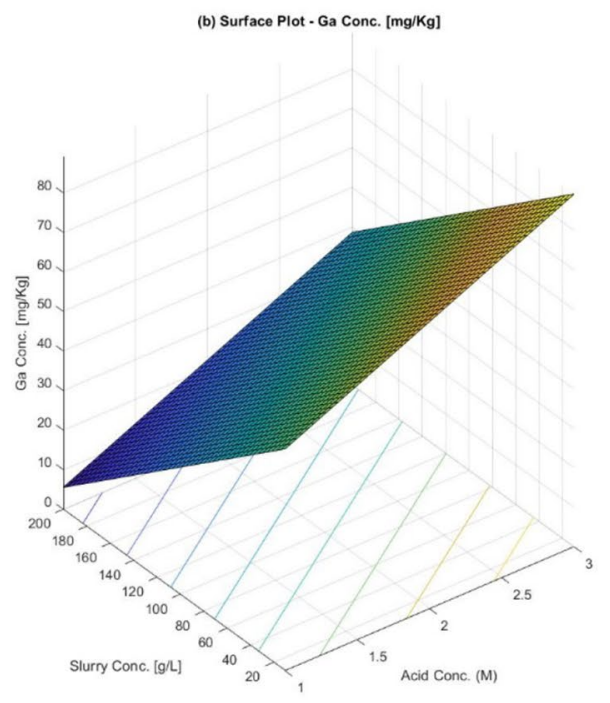

Fig. 2 Two-factor interactions (surface plot, left; contour plot, right) on the extracted Ga. Factors that are not shown in the graphs were held constant at the predicted optimal values (Color figure online) 

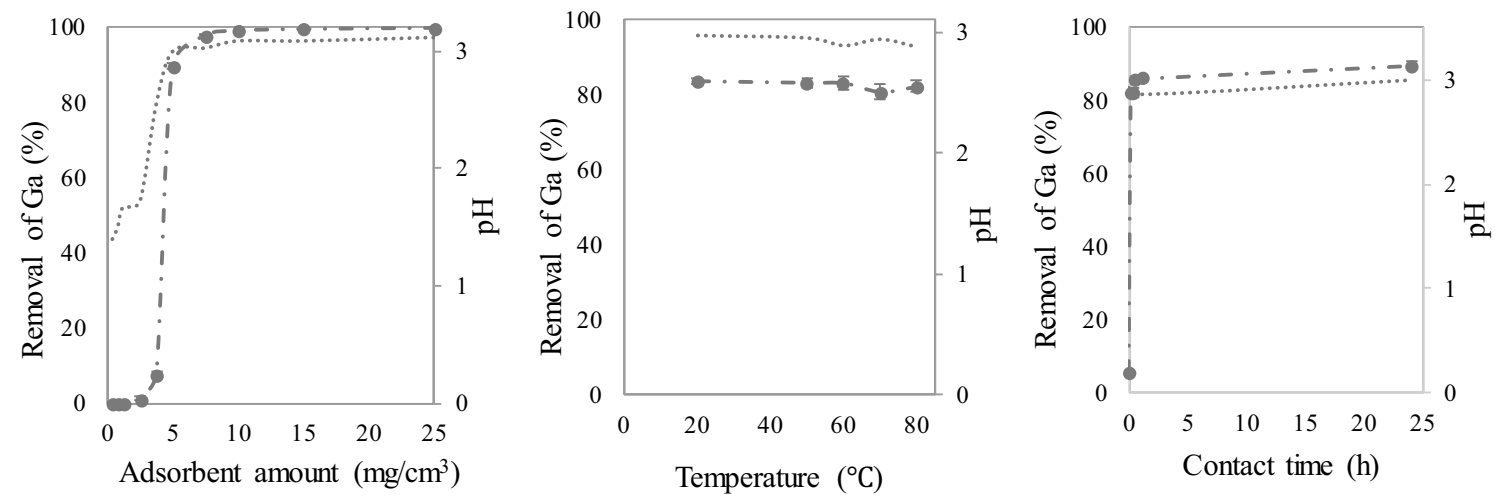

Fig. 3 Effects of adsorption parameters (adsorbent dosage, temperature, and contact time) on Ga removal efficiency (primary $Y$-axis) and $\mathrm{pH}$ (secondary $Y$-axis) from synthetic $\mathrm{Ga}(50 \mathrm{mg} / \mathrm{L})$ solution by

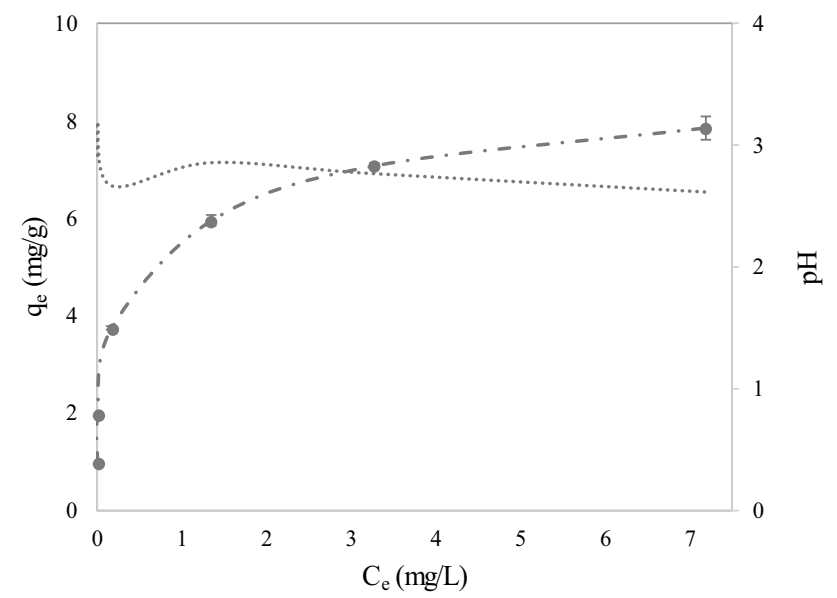

Fig. 4 Adsorption isotherm of $\mathrm{Ga}$ on zeolite HY under the following conditions: 10 -min contact time, $20^{\circ} \mathrm{C}\left(C_{e}\right.$ adsorbate equilibrium concentration, $q_{e}$ amount of adsorbate in the adsorbent at equilibrium)

on zeolite HY showed rapid kinetic as $82 \%(\sim 40.0 \mathrm{~g} / \mathrm{L})$ of $\mathrm{Ga}$ was adsorbed from the solution after $10 \mathrm{~min}$.

The adsorption equilibrium was correlated by a Langmuir-type equation; however, the curve did not reach any plateau (the adsorbent does not show clearly a limited sorption capacity) (Fig. 4) [41]. As shown in Fig. 4, the zeolite HY adsorbed Ga under the employed experimental condition, which shows that ion exchange can effectively remove Ga ion from acetic solution. The maximum amount of adsorbed Ga per zeolite HY was 7.9 ( $\mathrm{mg}$ of $\mathrm{Ga} / \mathrm{g}$ of zeolite HY).

Similar to the extraction study, in order to determine optimal removal conditions to remove maximal $\mathrm{Ga}$ from the solution, a DOE approach was used to account for interaction effects between investigated factors regarding adsorbent dosage $(0.4-25 \mathrm{mg} / \mathrm{mL})$, contact time $(0-24 \mathrm{~h})$, and zeolite HY. Single parameters were varied, whereas all other parameters were kept constant at $(5 \mathrm{mg} / \mathrm{mL}$ amount of adsorbent, $24 \mathrm{~h}$, and $\left.20{ }^{\circ} \mathrm{C}\right)$

temperature $\left(20-80{ }^{\circ} \mathrm{C}\right)(\mathrm{SI}$, Table 8$)$. The response surface-reduced linear model considered linear effects between adsorbent dosage and contact time (SI, Eq. 2) as they had a significant $(p \leq 0.05)$ effect on the Ga removal efficiency (SI, Table 9). The adsorbent dosage had the most pronounced effect on the Ga removal efficiency and was, therefore, the most important factor in the optimization (Fig. 5).

Optimal conditions predicted by the model regarding removal of maximal Ga from solution were $5 \mathrm{mg} / \mathrm{mL}$ adsorbent dosage and 1-h contact time, and $20{ }^{\circ} \mathrm{C}$. The model predicted maximal Ga removal efficiencies of $99.8 \%$. The corresponding adsorption experiment under these conditions was conducted, and it yielded a maximal Ga removal efficiency of $99.4 \%$. Since the experimentally determined and predicted maximal Ga removal efficiencies did not differ significantly (prediction was $99.6 \%$ of obtained), the model was considered accurate.

The developed optimal adsorption parameters $(5 \mathrm{mg} /$ $\mathrm{mL}$ adsorbent dosage, 1 -h contact time, and $20{ }^{\circ} \mathrm{C}$ ) were applied to bauxite residue $\mathrm{H}_{2} \mathrm{C}_{2} \mathrm{O}_{4}$ leachate (produced under optimal conditions, see "Design of Experiment Approach to Predict the Optimal Parameters for Leaching Experiments" section) to extract $\mathrm{Ga}$ from the leachate. In contrast to the batch study, $16.1 \%(\sim 17.8 \mathrm{mg} / \mathrm{kg}) \mathrm{Ga}$ was adsorbed with the presence of major elements onto bauxite residue (Al: $9.8 \%-13,419 \mathrm{mg} / \mathrm{kg}$, Ca: $14.0 \%-2739 \mathrm{mg} /$ $\mathrm{kg}$, Fe: $11.7 \%-39,018 \mathrm{mg} / \mathrm{kg}$, Na: $7.2 \%-5708 \mathrm{mg} / \mathrm{kg}$, Ti: $17.7 \%-7045 \mathrm{mg} / \mathrm{kg}, \mathrm{V}: 14.2 \%-210 \mathrm{mg} / \mathrm{kg}$ ) (Fig. 6; SI, Table 3).

\section{Study on the Byproduct of the Leaching}

The $\mathrm{pH}$ of the post residue was 0.3 with the $\mathrm{EC}$ of $39.1 \mathrm{mS} /$ $\mathrm{cm}$. The SEM analysis showed that the bauxite residue powder had a size of $<10 \mu \mathrm{m}$. Analyzing the exact size of 

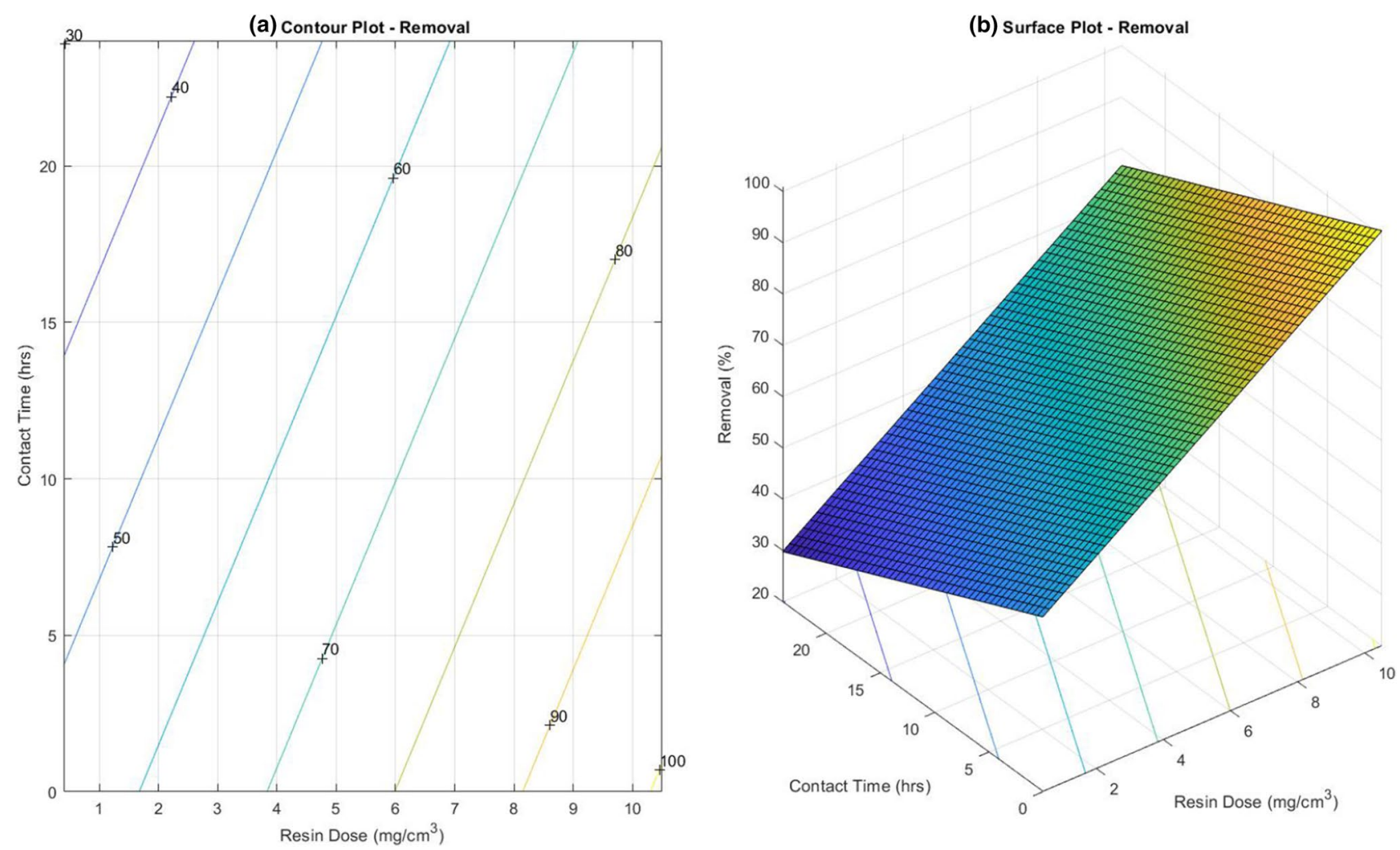

Fig. 5 Two-factor interactions (surface plot, left; contour plot, right) on the removal of Ga (\%). Factors that are not shown in the graphs were held constant at the predicted optimal values (Color figure online)

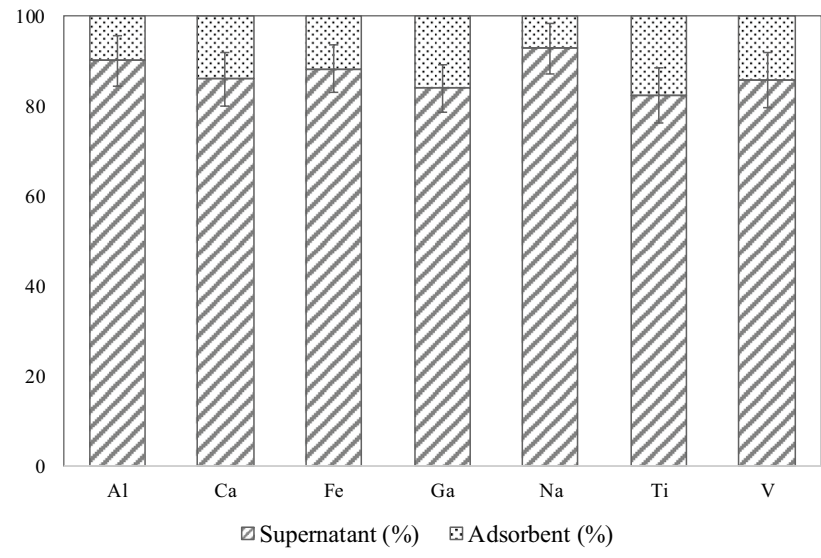

Fig. 6 Bauxite residue leachate compounds partitioning into supernatant and adsorbent during adsorption onto zeolite HY under the following conditions: $5 \mathrm{mg} / \mathrm{mL}, 1-\mathrm{h}$ contact time, $20^{\circ} \mathrm{C}(\mathrm{pH} 0.5)$

particles was not possible because of particles agglomeration (Fig. 7a). EDS mapping showed the presence of major components such as $\mathrm{Al}, \mathrm{Fe}, \mathrm{Na}, \mathrm{Si}, \mathrm{Ca}$ and Ti. Measuring the composition of the bauxite residue with EDX data was also limited due to the concentration of components. The detected dominance of elements by EDX: Fe, Al, Na, Si,
$\mathrm{Ca}$, and Ti oxides (SI, Table 10) corresponds to composition detected by XRF and ICP-OES.

SEM analysis showed that post residue formed large aggregates (Fig. 7b). EDS mapping showed that elements remained in acidic solid residue accumulated on the surface of the large aggregates. The EDX mapping of the post residue showed the presence of $\mathrm{Fe}, \mathrm{Al}, \mathrm{Si}, \mathrm{Ti}, \mathrm{Ca}$ and $\mathrm{Na}$ oxides (Fig. 7b; SI, Table 11).

\section{Discussion}

The typical order of elemental abundance in bauxite residue is $\mathrm{Fe}>\mathrm{Si} \sim \mathrm{Ti}>\mathrm{Al}>\mathrm{Ca}>\mathrm{Na}$ [42]. In this study, the elemental composition of the bauxite residue was dominated by (expressed as oxides) Fe ( 43.3\%), $\mathrm{Al}(\sim 16.5 \%)$, Si ( 9.4\%), Ti ( 8.9\%), Ca ( 6.2\%), and $\mathrm{Na}(\sim 6.0 \%)$ (SI, Table 2), and the aqua regia-accessible Ga concentration was $114.5 \pm 5.2 \mathrm{mg} / \mathrm{kg}$ (SI, Table 3). Similar Ga contents were described, for instance $89 \mathrm{mg} / \mathrm{kg}$, in Australian bauxite residue [43], as well as $91 \mathrm{mg} / \mathrm{kg}$ in Indian bauxite residue [44].

Similarly to Ujaczki et al. [18] in this study the extraction efficiency of $\mathrm{Ga}$ was higher using $\mathrm{H}_{2} \mathrm{C}_{2} \mathrm{O}_{4}$ in comparison to $\mathrm{HCl}, \mathrm{HNO}_{3}$ and $\mathrm{H}_{2} \mathrm{SO}_{4}$ under normality $=2,24 \mathrm{~h}, 60^{\circ} \mathrm{C}$ and $100 \mathrm{~g} / \mathrm{L}$ slurry concentration (SI, Table 4). Lu et al. [22] 

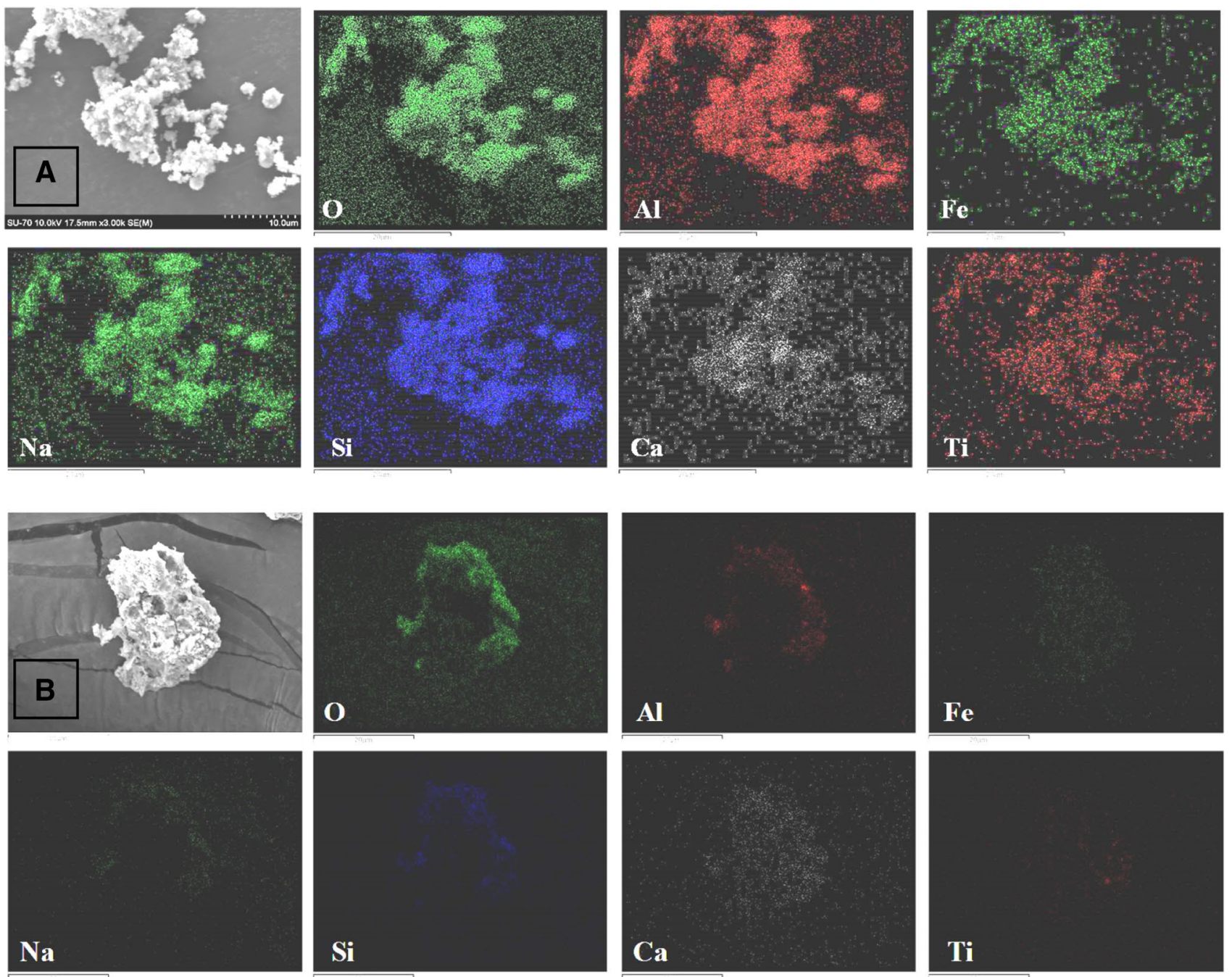

Fig. 7 Morphology and chemical composition of bauxite residue (a) and post residue (b) detected by SEM-EDS $(10.0 \mathrm{kV}, 17.5 \mathrm{~mm}, \times 3.00 \mathrm{k})$ (Color figure online)

also evaluated the effects of different mineral acids $(4.4 \mathrm{M}$ $\mathrm{HCl}, 2.2 \mathrm{M} \mathrm{H}_{2} \mathrm{SO}_{4}, 4.1 \mathrm{M} \mathrm{HNO}_{3}$ ) on the $\mathrm{Ga}$ extraction from bauxite residue at $4 \mathrm{~h}, 60^{\circ} \mathrm{C}, 125 \mathrm{~g} / \mathrm{L}$ slurry concentration. In their study leaching with $\mathrm{HCl}$ resulted greater efficiency than leaching with $\mathrm{H}_{2} \mathrm{SO}_{4}$ or $\mathrm{HNO}_{3}$ in accordance with the present and Ujaczki et al. [18] investigations.

Considering leaching parameters such as acid concentration, contact time, temperature and slurry concentration, general trends were observed. The extraction efficiencies depend largely on the acid concentration with more extraction achieved at higher acid concentrations [18, 22]. For instance, $\mathrm{Lu}$ et al. [22] reported a significant increase in $\mathrm{Al}$ and $\mathrm{Ga}$ extraction efficiency from 81 to $95 \%$ when the $\mathrm{HCl}$ concentration increased from 4.4 to $6.5 \mathrm{M}$ at $4 \mathrm{~h}, 100{ }^{\circ} \mathrm{C}$ and $125 \mathrm{~g} / \mathrm{L}$ slurry concentration. They found a slight improvement in $\mathrm{Al}$ and $\mathrm{Ga}$ extraction efficiency from 4.4 to $5.8 \mathrm{M}$ $\mathrm{HCl}$, then both $\mathrm{Al}$ and $\mathrm{Ga}$ extraction efficiency increased remarkably from 5.8 to $6.5 \mathrm{M} \mathrm{HCl}$. They attributed this to the initial extraction of only the most easily digested $\mathrm{Al}$ (Ga) phases in bauxite residue e.g. kaolinite at lower acid concentrations. Here, increasing the $\mathrm{H}_{2} \mathrm{C}_{2} \mathrm{O}_{4}$ concentration from 0.05 to $3 \mathrm{M}$ increased extraction efficiencies of $\mathrm{Al}$ and $\mathrm{Ga}$ from 3 and 1 to 44 and $60 \%$, respectively at $24 \mathrm{~h}, 60^{\circ} \mathrm{C}$, $100 \mathrm{~g} / \mathrm{L}$ slurry concentration (Fig. 1).

Other studies showed similar effects of contact time on extraction of $\mathrm{Ga}$ from bauxite residue. For example, $\mathrm{Lu}$ et al. [22] reported that increasing the contact time from 1 to $5 \mathrm{~h}$ led to increased extraction efficiencies from 82 to $95 \%$ at $4.4 \mathrm{M} \mathrm{HCl}, 55{ }^{\circ} \mathrm{C}$ and $125 \mathrm{~g} / \mathrm{L}$ slurry concentration. They found an increase Ga extraction efficiency from 94 to $95 \%$ at $4-5-\mathrm{h}$ contact time, therefore $4 \mathrm{~h}$ was chosen as the optimal extraction time in their study. In Ujaczki et al. [18] the best results regarding contact time was achieved at $3 \mathrm{~h}$, showing $63 \%$ Ga extraction efficiency at $4 \mathrm{M} \mathrm{HCl}$, 
$60{ }^{\circ} \mathrm{C}$ and $100 \mathrm{~g} / \mathrm{L}$ slurry concentration. Ujaczki et al. [18] found relatively low $\mathrm{Fe}$ extraction efficiency $(21 \%)$ at $3 \mathrm{~h}$ but the $\mathrm{Al}$ extraction efficiency was already high after the first hour (72\%). In this study, increasing the contact time from 1 to $24 \mathrm{~h}$ increased extraction efficiencies of $\mathrm{Ga}$ from 12 to $38 \%$ using $1 \mathrm{M} \mathrm{H}_{2} \mathrm{C}_{2} \mathrm{O}_{4}, 60{ }^{\circ} \mathrm{C}$ and $100 \mathrm{~g} / \mathrm{L}$ slurry concentration. A slight increase was detectable at increasing contact time from 1 to $24 \mathrm{~h}$ for $\mathrm{Al}$ (from 44 to 57\%) (Fig. 1).

According to Davris et al. [45] and Pepper et al. [46] temperature plays a crucial role in the bauxite residue dissolution. The extraction of aluminosilicate $(\mathrm{Ga})$ phases in bauxite residue has been shown to increase with the increasing reaction temperatures. In Lu et al. [22] study, the extraction efficiency of $\mathrm{Ga}$ increased from 89 to $94 \%$ when the temperature increased from 40 to $55^{\circ} \mathrm{C}$, while they found a slight increase from 55 to $100{ }^{\circ} \mathrm{C}$. In the present study, elevating temperature from 22 to $80{ }^{\circ} \mathrm{C}$ led to considerably increased extraction efficiencies of $\mathrm{Ga}$ from 18 to $40 \%$ using $1 \mathrm{M} \mathrm{H}_{2} \mathrm{C}_{2} \mathrm{O}_{4}, 24 \mathrm{~h}, 100 \mathrm{~g} / \mathrm{L}$ and slurry concentration (Fig. 1). Elevated temperatures increased $\mathrm{Al}$ extraction efficiency for $63 \% \mathrm{Al}$ while $\mathrm{Fe}$ still remained $21 \%$.

Slurry concentration had a strong effect on extraction efficiencies similar to acid concentration. Here, decreasing the slurry concentration from 200 to $10 \mathrm{~g} / \mathrm{L}$ resulted in an increase in extraction efficiencies of $\mathrm{Ga}$ from 3 to $47 \%$ using $1 \mathrm{M} \mathrm{H}_{2} \mathrm{C}_{2} \mathrm{O}_{4}, 24 \mathrm{~h}$ and $60{ }^{\circ} \mathrm{C}$ (Fig. 1). The maximal $\mathrm{Al}$ and $\mathrm{Fe}$ extraction efficiencies were also achieved with decreasing slurry concentration at $10 \mathrm{~g} / \mathrm{L}$ when $62 \% \mathrm{Al}$ and $62 \% \mathrm{Fe}$ were extracted. This is in accordance with Ujaczki et al. [18]. However, Lu et al. [22] did not find significant improvement in the $\mathrm{Ga}$ and $\mathrm{Al}$ extraction efficiency. They found that the slurry (bauxite residue and $\mathrm{HCl}$ acid solution) filtration was quite difficult when the slurry concentration was below $125 \mathrm{~g} / \mathrm{L}$, which could be attributed to a high concentration of formed silica gels in the slurry [47, 48]. Kinetic studies performed by Rivera et al. [17] with $\mathrm{HCl}$ and $\mathrm{H}_{2} \mathrm{SO}_{4}$ demonstrated that, at ambient temperatures, silica dissolution increases with increasing acid concentration, which leads to the formation of silica gel.

Based on the conducted experiments, Lu et al. [22] determined optimum leaching conditions for $\mathrm{Ga}$ extraction from bauxite residue as the follow: $4.4 \mathrm{M} \mathrm{HCl}, 4$-h contact time, $55{ }^{\circ} \mathrm{C}$ temperature, and $125 \mathrm{~g} / \mathrm{L}$ slurry concentration. Under these optimal conditions, 95\% average Ga extraction efficiency was reached. Here, an experimental design approach was used to determine optimal conditions for $\mathrm{Ga}$ extraction using $\mathrm{H}_{2} \mathrm{C}_{2} \mathrm{O}_{4}$. Extraction of maximal $\mathrm{Ga}$ from bauxite residue was chosen as the application relevant response viable. Optimal conditions for extraction of maximal $\mathrm{Ga}$ from bauxite residue were predicted for $2.5 \mathrm{M} \mathrm{H}_{2} \mathrm{C}_{2} \mathrm{O}_{4}$ acid concentration, 21.7-h contact time, $80.0^{\circ} \mathrm{C}$ temperature, and $10.0 \mathrm{~g} / \mathrm{L}$ slurry concentration. Indeed, experimentally determined economic potential corresponded well (93\% of predicted) with the predictions, allowing a maximum extracted $\mathrm{Ga}$ of $85.8 \mathrm{mg} / \mathrm{kg}$. Using these optimal conditions, $71 \%$ of the aqua regia-accessible Ga content was extracted in bauxite residue.

Many strategies for valuable elements recovery from bauxite residue requires large amounts of energy and chemicals [15, 18, 20-22, 28-30, 45, 49]. However, the extraction of strategically important elements from bauxite residue is not only attractive from the financial point of view of recovered elements alone. It is also motivated by a number of factors such as economic, social, environmental and technological benefits [6].

For instance, extraction by $\mathrm{H}_{2} \mathrm{C}_{2} \mathrm{O}_{4}$, can be biologically produced, showing a potential for bioleaching as a green alternative for the extraction. Bioleaching for valuable element recovery offers eco-efficient alternatives to classical pyro- or hydrometallurgical processes as it is an energy efficient process and the highly selective metal(loid) microbe interactions offer the possibility to unite bioremediation with resource recovery for many elements [5]. Bioleaching of $\mathrm{Ga}, \mathrm{Ge}, \mathrm{V}, \mathrm{Sc}, \mathrm{La}, \mathrm{Eu}$, and $\mathrm{Yb}$ from bauxite residue was investigated by $\mathrm{Qu}$ et al. [50]. In their study, Aspergillus niger showed almost the same metal leaching efficiencies as that by the commercial citric acid $\left(\mathrm{C}_{6} \mathrm{H}_{8} \mathrm{O}_{7}\right)$ at half its cost. In general, the growth of fungi in sugar-containing media results in the production of organic acids such as $\mathrm{H}_{2} \mathrm{C}_{2} \mathrm{O}_{4}$, $\mathrm{C}_{6} \mathrm{H}_{8} \mathrm{O}_{7}$, and gluconic acid $\left(\mathrm{C}_{6} \mathrm{H}_{12} \mathrm{O}_{7}\right)$ [51]. Studies also have shown that the alkaline medium favors $\mathrm{H}_{2} \mathrm{C}_{2} \mathrm{O}_{4}$ production which is also beneficial in the application to an alkaline byproduct such as bauxite residue [51, 52].

Rivera et al. [17] showed high extraction efficiency of REE from bauxite residue in a two-step processing of bauxite residue by dry digestion and subsequent water leaching. They found that the low water consumption allows to increase the filtration efficiency of the leach liquor due to the avoidance of silica gel formation [17]. In this integrated multistage treatment, much more bauxite residue can be processed for REEs extraction without demanding too much water for the process [17]. Therefore, an increase in bauxite residue processing may help to reduce the inventories and costs associated with storing, which are major concerns for the alumina producers [17].

After extraction, dissolved Ga is mostly separated using solvent extraction [53-57]. Solvent extraction (liquid/liquid extraction) is based on the partitioning of the dissolved metal into a nonmiscible organic phase (extract), followed by recovery (stripping) of the metal from the solvent phase [58]. However, the solvents used during liquid-liquid extraction perform well technologically, certain processing steps have a comparably higher environmental impact [59].

Adsorption as a separation process is also available as another possibility due to its apparent lower environmental impact, high efficiency, easy operation and low price in 
comparison to conventionally used solvents [60]. In recent years, zeolites have been investigated for the adsorption of metals owing to their net negative charge in the polymeric network and to the fact that zeolite exchangeable ions are relatively innocuous [61-63]. The structure of zeolite consists of a three-dimensional framework of $\mathrm{SiO}_{4}$ and $\mathrm{AlO}_{4}$ tetrahedra where the $\mathrm{Al}^{3+}$ is small enough to occupy the position in the center of the tetrahedron of four oxygen atoms and the isomorphous replacement of $\mathrm{Si}^{4+}$ by $\mathrm{Al}^{3+}$ produces a negative charge in the lattice [61]. The net negative charge is balanced by the exchangeable cation $\left(\mathrm{Na}^{+}, \mathrm{K}^{+}, \mathrm{NH}_{4}^{+}\right.$or $\left.\mathrm{Ca}^{2+}\right)$, and these cations are exchangeable with certain cations [61]. In Zhao et al. [60], a magnetic cobalt ferrite $\left(\mathrm{CoFe}_{2} \mathrm{O}_{4}\right)$-coated zeolite was prepared using a hydrothermal method and was used for the adsorption of Ga and In. They investigated the effects of $\mathrm{pH}$ and adsorption time as the adsorption capacity was influenced by these parameters. In their experiments, the adsorption equilibria of $\mathrm{Ga}$ and $\mathrm{In}$ on $\mathrm{CoFe}_{2} \mathrm{O}_{4}$-zeolite could be achieved very quickly. The optimum $\mathrm{pH}$ was chosen as 5.0 because at lower $\mathrm{pH}$, more hydrogen ions exist, which can compete more effectively with Ga and In for active bonding sites, leading to lower adsorption capacity [60]. However, high $\mathrm{pH}$ also can lead to lower adsorption capacity, which is attributed to the formation of $\mathrm{Ga}(\mathrm{OH})_{3}$ and $\operatorname{In}(\mathrm{OH})_{3}[60]$. According to Zhao et al. [60], the rapid and high adsorption efficiency was attributed to the presence of active sites on the adsorbent's surface in a large scale. In the present study, Ga adsorption onto zeolite HY showed rapid adsorption kinetic too, as $82 \%$ of Ga was adsorbed from the solution after $10 \mathrm{~min}$ (Fig. 5). The $\mathrm{pH}$ was kept low because the developed parameters in the batch experiments were applied on an acidic (pH 0.5) leachate to adsorb Ga. Identified future challenges to optimize Ga-adsorption techniques are (1) concentration of Ga in adsorbent from the leachate (2) improving selectivity of $\mathrm{Ga}$ against major components (e.g., $\mathrm{Al}$ and $\mathrm{Fe}$ ) (3) developing recovery step from the adsorbent or finding a market where Ga bound to zeolite network can be utilized, and (4) regeneration of adsorbent. Moreover, challenges related to the post-residue production during Ga extraction from bauxite residue need to be also addressed. Due to the oxalic acid applied for the extraction of $\mathrm{Ga}$, the byproduct produced is highly acidic ( $\mathrm{pH} 0.3$ ) compared to the original alkaline $\mathrm{pH}$ of the bauxite residue (10.9) (see in "Physicochemical and Mineralogical Characterization" and "Study on the Byproduct of the Leaching" sections), which warrants further investigations for its disposal and/or utilization.

\section{Conclusion}

In the present study, the extractions of $\mathrm{Ga}$ from bauxite residue by mineral acids $\left(\mathrm{H}_{2} \mathrm{SO}_{4}, \mathrm{HCl}\right.$, and $\left.\mathrm{HNO}_{3}\right)$ and an organic acid $\left(\mathrm{H}_{2} \mathrm{C}_{2} \mathrm{O}_{4}\right)$ were evaluated regarding their efficiencies which showed that the most efficient extraction for $\mathrm{Ga}$ was achieved by $\mathrm{H}_{2} \mathrm{C}_{2} \mathrm{O}_{4}$ followed by the other acids in the order $\mathrm{HCl}>\mathrm{H}_{2} \mathrm{SO}_{4}>\mathrm{HNO}_{3}$. Experimental design (DOE) software was used for the optimization of Ga extraction by $\mathrm{H}_{2} \mathrm{C}_{2} \mathrm{O}_{4}$ from bauxite residue where the prediction was validated with laboratory experiments. Optimal conditions predicted by the model regarding extraction of maximal Ga from bauxite residue were $2.5 \mathrm{M} \mathrm{H}_{2} \mathrm{C}_{2} \mathrm{O}_{4}$ acid concentration, 21.7-h contact time, $80.0{ }^{\circ} \mathrm{C}$ temperature, and $10.0 \mathrm{~g} / \mathrm{L}$ slurry concentration. In the subsequent sections, the effects of adsorbent dosage, temperature, and contact time on the removal of Ga by zeolite HY from synthetic Ga solution were studied. Similar to the extraction study, DOE approach was used to predict optimal conditions for maximal Ga removal from the synthetic Ga solution when the optimal conditions determined were $5 \mathrm{mg} / \mathrm{mL}$ adsorbent dosage and 1 -h contact time, and $20^{\circ} \mathrm{C}$. The corresponding adsorption experiments under these conditions from synthetic Ga solution were conducted, and they yielded a maximal Ga removal efficiency of $99.4 \%$. However, adsorption, under optimal conditions, on zeolite $\mathrm{HY}$ for recovering $\mathrm{Ga}$ from $\mathrm{H}_{2} \mathrm{C}_{2} \mathrm{O}_{4}$ leachate showed only $16 \%$ efficiency for $\mathrm{Ga}$.

Acknowledgements Open access funding provided by Budapest University of Technology and Economics (BME). The authors would like to acknowledge the financial support of the Environmental Protection Agency EPA (2014-RE-MS-1).

\section{Compliance with Ethical Standards}

Conflict of interest On behalf of all authors, the corresponding author states that there is no conflict of interest.

Open Access This article is distributed under the terms of the Creative Commons Attribution 4.0 International License (http://creativeco mmons.org/licenses/by/4.0/), which permits unrestricted use, distribution, and reproduction in any medium, provided you give appropriate credit to the original author(s) and the source, provide a link to the Creative Commons license, and indicate if changes were made.

\section{References}

1. European Commission, EC (2017) Communication from the Commission to the European Parliament, the Council, the European Economic and Social Committee and the Committee of the Regions on the 2017 list of critical raw materials for the EU. https ://eur-lex.europa.eu/legal-content/EN/TXT/?uri=CELEX:52017 DC0490. Accessed 3 Aug 2018

2. Kawamoto H (2008) Japan's policies to be adopted on rare metal resources. Q Rev 27:57-76. https://data.nistep.go.jp/dspace/bitst ream/11035/2772/1/NISTEP-STT027E-57.pdf. Accessed 6 June 2018

3. Natural Resources Canada Website (2017) Mining/materials, mining, policy. The minerals and Metals Policy of the Government of Canada. https://www.nrcan.gc.ca/mining-materials/policy/8690. Accessed 6 June 2018 
4. US National Research Council (2008) Minerals, critical minerals, and the U.S. economy. The National Academies Press, Washington, DC. doi: 10.17226/12034

5. Hennebel T, Boon N, Maes S, Lenz M (2015) Biotechnologies for critical raw materials recovery from primary and secondary sources: R\&D priorities and future perspectives. N Biotechnol 32(1):121-127. https://doi.org/10.1016/j.nbt.2013.08.004

6. Ujaczki É, Feigl V, Molnár M, Cusack P, Curtin T, Courtney R, O'Donoghue L, Davris P, Hugi C, Evangelou MWH, Balomenos E, Lenz M (2018) Re-using bauxite residues: benefits beyond (critical raw) material recovery. J Chem Technol Biotechnol. https ://doi.org/10.1002/jctb.5687

7. Liu Y, Naidu R (2014) Hidden values in bauxite residue (red mud): recovery of metals. Waste Manag 34(12):2662-2673. https ://doi.org/10.1016/j.wasman.2014.09.003

8. Binnemans K, Jones PT, Blanpain B, Van Gerven T, Pontikes Y (2015) Towards zero-waste valorisation of rare-earth-containing industrial process residues: a critical review. J Clean Prod 99:1738. https://doi.org/10.1016/j.jclepro.2015.02.089

9. Evans K (2016) The History, Challenges, and new developments in the management and use of bauxite residue. J Sustain Metall 2(4):316-331. https://doi.org/10.1007/s40831-016-0060-x

10. Balomenos E, Panias D (2013) Iron recovery and production of high added value products from the metallurgical by-products of primary aluminum and ferronickel industries. In: Proceedings of 3rd international slag valorisation symposium, Leuven, Belgium, pp 161-172

11. Erçă E, Apak R (1997) Furnace smelting and extractive metallurgy of red mud: recovery of $\mathrm{TiO}_{2}, \mathrm{Al}_{2} \mathrm{O}_{3}$ and pig iron. J Chem Technol Biotechnol 70:241-246. https://doi. org/10.1002/(SICI)1097-4660(199711)70:3\%3C241:AID-JCTB7 69\%3E3.0.CO;2-X

12. Kaußen F, Friedrich B (2015) Reductive smelting of red mud for iron recovery. Chem Ing Tech 87:1535-1542. https://doi. org/10.1002/cite.201500067

13. Jayasankar K, Ray PK, Chaubey AK, Padhi A, Satapathy BK, Mukherjee PS (2012) Production of pig iron from red mud waste fines using thermal plasma technology. Int J Miner Metall Mater 19:679-684. https://doi.org/10.1007/s12613-012-0613-3

14. Raspopov NA, Korneev VP, Averin VV, Lainer YA, Zinoveev DV, Dyubanov VG (2013) Reduction of iron oxides during the pyrometallurgical processing of red mud. Russ Metall 1:33-37. https://doi.org/10.1134/S0036029513010114

15. Borra CR, Mermans J, Blanpain B, Pontikes Y, Binnemans K, Van Gerven T (2016) Selective recovery of rare earths from bauxite residue by combination of sulfation, roasting and leaching. Miner Eng 92:151-159. https://doi.org/10.1016/j.mineng.2016.03.002

16. Reid S, Tam J, Yang M, Azimi G (2017) Technospheric mining of rare earth elements from bauxite residue (red mud): process optimization, kinetic investigation, and microwave pretreatment. Sci Rep 7:15252. https://doi.org/10.1038/s41598-017-15457-8

17. Rivera RM, Ulenaers B, Ounoughene G, Binnemans K, Van Gerven $\mathrm{T}$ (2018) Extraction of rare earths from bauxite residue (red mud) by dry digestion followed by water leaching. Miner Eng 119:82-92. https://doi.org/10.1016/j.mineng.2018.01.023

18. Ujaczki É, Zimmermann YS, Gasser CA, Molnár M, Feigl V, Lenz M (2017) Red mud as secondary source for critical raw materials-extraction study. J Chem Technol Biotechnol 92(11):28352844. https://doi.org/10.1002/jctb.5300

19. Ujaczki É, Zimmermann YS, Gasser CA, Molnár M, Feigl V, Lenz M (2017) Red mud as secondary source for critical raw materials - purification of rare earth elements by liquid/liquid extraction. J Chem Technol Biotechnol 92:2683-2690. https:// doi.org/10.1002/jctb.5289

20. Borra CR, Blanpain B, Pontikes Y, Binnemans K, Van Gerven T (2015) Smelting of bauxite residue (red mud) in view of iron and selective rare earths recovery. J Sustain Metall 2:28-37. https:// doi.org/10.1007/s40831-015-0026-4

21. Abdulvaliyev RA, Akcil A, Gladyshev SV, Tastanov EA, Beisembekova KO, Akhmadiyeva NK, Deveci H (2015) Gallium and vanadium extraction from red mud of Turkish alumina refinery plant: hydrogarnet process. Hydrometallurgy 157:72-77. https:// doi.org/10.1016/j.hydromet.2015.07.007

22. Lu F, Xiao T, Lin J, Li A, Long Q, Huang F, Xiao L, Li X, Wang J, Xiao Q, Chen H (2018) Recovery of gallium from Bayer red mud through acidic-leaching-ion-exchange process under normal atmospheric pressure. Hydrometallurgy 175:124-132. https://doi. org/10.1016/j.hydromet.2017.10.032

23. European Commission, EC (2011) Communication from the Commission to the European Parliament, the Council, the European Economic and Social Committee and the Committee of the Regions tackling the challenges in commodity markets and on raw materials. https://eur-lex.europa.eu/legal-content/EN/ TXT/?uri=CELEX:52011DC0025. Accessed 3 Aug 2018

24. European Commission, EC (2014) Communication from the Commission to the European Parliament, the Council, the European Economic and Social Committee and the Committee of the Regions on the review of the list of critical raw materials for the EU and the implementation of the raw materials initiative. https ://eur-lex.europa.eu/legal-content/EN/TXT/?uri=CELEX:52014 DC0297. Accessed 3 Aug 2018

25. U.S. Department of Energy (2010) Appendix A: criticality assessments by element. In: Chu S (ed) Critical materials strategy. ISBN 978-1-4379-4418-1

26. Foley NK, Jaskula BW, Kimball BE, Schulte RF (2017) Gallium. In: Schulz KJ, DeYoung JH, Seal II Jr RR, Bradley DC (eds) Chapter $\mathrm{H}$ of critical mineral resources of the United States-economic and environmental geology and prospects for future supply. US Department of the Interior, US Geological Survey. https:// pubs.er.usgs.gov/publication/pp1802H. Accessed 8 June 2018

27. Foley NK, Jaskula B (2013) Gallium —a smarter metal. US Geological Survey fact sheet. https://pubs.usgs.gov/fs/2013/3006/pdf/ fs2013-3006.pdf. Accessed 8 June 2018

28. Borra CR, Pontikes Y, Binnemans K, Van Gerven T (2015) Leaching of rare earths from bauxite residue (red mud). Miner Eng 76:20-27. https://doi.org/10.1016/j.mineng.2015.01.005

29. Hatzilyberis K, Lymperopoulou T, Tsakanika LA, Ochsenkühn KM, Georgiou P, Defteraios N, Tsopelas F, Ochsenkühn-Petropoulou M (2018) Process design aspects for scandium-selective leaching of bauxite residue with sulfuric acid. Minerals 8(3):79. https://doi.org/10.3390/min8030079

30. Ochsenkühn-Petropoulou M, Lyberopulu T, Ochsenkühn KM, Parissakis G (1996) Recovery of lanthanides and yttrium from red mud by selective leaching. Anal Chim Acta 319:249-254. https://doi.org/10.1016/0003-2670(95)00486-6

31. Liu W, Sun S, Zhang L, Jahanshahi S, Yang J (2012) Experimental and simulative study on phase transformation in Bayer red mud soda-lime roasting system and recovery of $\mathrm{Al}, \mathrm{Na}$ and $\mathrm{Fe}$. Miner Eng 39:213-218. https://doi.org/10.1016/j.mineng.2012.05.021

32. Zhu DQ, Chun TJ, Pan J, He Z (2012) Recovery of iron from high-iron red mud by reduction roasting with adding sodium salt. J Iron Steel Res Int 19:1-5. https://doi.org/10.1016/S1006 -706X(12)60131-9

33. Borra CR, Blanpain B, Pontikes Y, Binnemans K, Van Gerven $\mathrm{T}$ (2016) Recovery of rare earths and other valuable metals from bauxite residue (red mud): a review. J Sustain Metall 2:365-386. https://doi.org/10.1007/s40831-016-0068-2

34. Liu Z, Li H (2015) Metallurgical process for valuable elements recovery from red mud-a review. Hydrometallurgy 155:29-43. https://doi.org/10.1016/j.hydromet.2015.03.018

35. Wang W, Pranolo Y, Cheng CY (2011) Metallurgical processes for scandium recovery from various resources: a review. 
Hydrometallurgy 108:100-108. https://doi.org/10.1016/j.hydro met.2011.03.001

36. Zhang N, Li HX, Liu XM (2016) Recovery of scandium from bauxite residue-red mud: a review. Rare Met 35:887-900. https ://doi.org/10.1007/s12598-016-0805-5

37. Courtney R, Harrington T (2010) Assessment of plant-available phosphorus in a fine textured sodic substrate. Ecol Eng 36(4):542547. https://doi.org/10.1016/j.ecoleng.2009.12.001

38. Bridger S, Knowles M (2010) A complete method for environmental samples by simultaneous axially viewed ICPOES following US EPA guidelines. https://www.agilent.com/cs/library/applications/ ICPES-29.pdf. Accessed 5 June 2018

39. Cusack PB, Courtney R, Healy MG, O’Donoghue LMT, Ujaczki E (2019) An evaluation of the general composition and critical raw material content of bauxite residue in a storage area over a twelveyear period. J Clean Prod 208:393-401. https://doi.org/10.1016/j. jclepro.2018.10.083

40. Ujaczki É, Cusack P, Clifford S, Curtin T, Courtney R, O'Donoghue L (2017c) Bauxite residue as a source of galliuman extraction study. In: Travaux 46, proceedings of 35th international ICSOBA conference, Hamburg, Germany, pp 485-490

41. Foo KY, Hameed BH (2010) Insights into the modeling of adsorption isotherm systems. Chem Eng J 156:2-10. https://doi. org/10.1016/j.cej.2009.09.013

42. Gräfe M, Power G, Klauber C (2011) Bauxite residue issues: III. Alkalinity and associated chemistry. Hydrometallurgy 108(12):60-79. https://doi.org/10.1016/j.hydromet.2011.02.004

43. Wang W, Pranolo Y, Cheng CY (2013) Recovery of scandium from synthetic red mud leach solutions by solvent extraction with D2EHPA. Sep Purif Technol 108:96-102. https://doi. org/10.1016/j.seppur.2013.02.001

44. Mohapatra BK, Mishra BK, Mishra CR (2012) Studies on metal flow from khondalite to bauxite to alumina and rejects from an alumina refinery, India. In: Suarez CE (ed) Light metals 2012, pp 87-90. https://doi.org/10.1007/978-3-319-48179-1_16

45. Davris P, Balomenos E, Panias D, Paspaliaris I (2016) Selective leaching of rare earth elements from bauxite residue (red mud), using a functionalized hydrophobic ionic liquid. Hydrometallurgy 164:125-165. https://doi.org/10.1016/j.hydromet.2016.06.012

46. Pepper RA, Couperthwaite SJ, Millar GJ (2016) Comprehensive examination of acid leaching behaviour of mineral phases from red mud: recovery of $\mathrm{Fe}, \mathrm{Al}$, Ti, and Si. Miner Eng 99:8-18. https ://doi.org/10.1016/j.mineng.2016.09.012

47. Fang Z, Gesser HD (1996) Recovery of gallium from coal fly ash. Hydrometallurgy 41(2-3):187-200. https://doi.org/10.1016/0304386X(95)00055-L

48. Liu F, Liu Z, Li Y, Liu Z, Li Q, Zeng L (2016) Extraction of gallium and germanium from zinc refinery residues by pressure acid leaching. Hydrometallurgy 164:313-320. https://doi. org/10.1016/j.hydromet.2016.06.006

49. Paramguru RK, Rath PC, Misra VN (2006) Trends in red mud utilization-a review. Miner. Process Extr Metall Rev 26:1-29. https://doi.org/10.1080/08827500490477603

50. Qu Y, Li H, Tian W, Wang X, Wang X, Jia X, Shi B, Song G, Tang Y (2015) Leaching of valuable metals from red mud via batch and continuous processes by using fungi. Miner Eng 81:1-4. https:// doi.org/10.1016/j.mineng.2015.07.022
51. Xu TJ, Ramanathan T, Ting YP (2014) Bioleaching of incineration fly ash by Aspergillus niger-precipitation of metallic salt crystals and morphological alteration of the fungus. Biotechnol Rep 3:8-14. https://doi.org/10.1016/j.btre.2014.05.009

52. Kubicek C, Schreferl-Kunar G, Wohrer W, Rohr M (1988) Evidence for a cytoplasmic pathway of oxalate biosynthesis in Aspergillus niger. Appl Environ Microbiol 54:633-637

53. Chen WS, Huang SL, Chang FC, Chang JE, Wang YN (2014) Separation of gallium and copper from hydrochloric acid by D2EHPA. Desalin Water Treat 54(4-5):1-5. https://doi. org/10.1080/19443994.2014.929035

54. Mihaylov I, Distin PA (1993) Solvent extraction of gallium with D2EHPA from acidic sulphate solutions-equilibria and complexation. Can Metall Q 32(1):21-30. https://doi.org/10.1179/ cmq.1993.32.1.21

55. Tsai HS, Tsai TH (2013) Extraction equilibrium of gallium(III) from nitric acid solutions by di(2-ethylhexyl)phosphoric acid dissolved in kerosene. Asian J Chem 25(3):1429-1433. https://doi. org/10.14233/ajchem.2013.13055

56. Lee MS, Ahn JG, Lee EC (2002) Solvent extraction separation of indium and gallium from sulphate solutions using D2EHPA. Hydrometallurgy 63:269-276. https://doi.org/10.1016/S0304 $-386 X(02) 00004-X$

57. Nishihama S, Hirai T, Komasawa I (1999) Separation and recovery of gallium and indium from simulated zinc refinery residue by liquid-liquid extraction. Ind Eng Chem Res 38:1032-1039. https ://doi.org/10.1021/ie980510q

58. Free ML (2013) Hydrometallurgy: Fundamentals and applications. Wiley. https://doi.org/10.1002/9781118732465

59. Vahidi E, Zhao F (2017) Environmental life cycle assessment on the separation of rare earth oxides through solvent extraction. J Environ Manag 1(203, Pt 1):255-263. https://doi.org/10.1016/j. jenvman.2017.07.076

60. Zhao F, Zou Y, Lv X, Liang H, Jia Q, Ning W (2015) Synthesis of $\mathrm{CoFe}_{2} \mathrm{O}_{4}$-zeolite materials and application to the adsorption of gallium and indium. J Chem Eng Data 60:1338-1344. https:// doi.org/10.1021/je501039u

61. Erdem E, Karapinar N, Donat R (2004) The removal of heavy metal cations by natural zeolites. J Colloid Interface Sci 280:309314. https://doi.org/10.1016/j.jcis.2004.08.028

62. Chao HP, Chen SH (2012) Adsorption characteristics of both cationic and oxyanionic metal ions on hexadecyltrimethylammonium bromide-modified NaY zeolite. Chem Eng 193-194:283-289. https://doi.org/10.1016/j.cej.2012.04.059

63. Bao WW, Zou HF, Gan SC, Xu XC, Ji GJ, Zheng KY (2013) Adsorption of heavy metal ions from aqueous solutions by zeolite based on oil shale ash: kinetic and equilibrium studies. Chem Res Chin Univ 29:126-131. https://doi.org/10.1007/s4024 2-013-2139-2

Publisher's Note Springer Nature remains neutral with regard to jurisdictional claims in published maps and institutional affiliations. 